\title{
Usability of Electronic Records Management System (ERMS) of the Republic of Turkey Ministry of Health
}

\section{Türkiye Cumhuriyeti Sağlık Bakanlığı Elektronik Belge Yönetim Sisteminin (EBYS) Kullanılabilirliği}

\section{Semanur Öztemiz*}

\begin{abstract}
The purpose of this study is to evaluate the usability of ERMS concerning the case of the Republic of Turkey Ministry of Health, which is one of the most important institutions of Turkey. Quantitative and qualitative methods are used together in the study. Usability of ERMS, alongside a task-based application, is analyzed by interviews based on evaluating system \& user interactions. Findings showed that participants evaluate the Republic of Turkey Ministry of Health ERMS satisfying and trustworthy while it has some weak points. According to participants, a sort of enhancements, particularly educational videos and user feedback, which will increase usability, seemed inevitable. It's thought that results of this study, which is expected to contribute to the literature, can provide an exemplary ERMS - user experience for researchers and system developers.
\end{abstract}

Keywords: Usability; electronic records management systems; ERMS of Republic of Turkey Ministry of Health.

\section{$\ddot{O}_{z}$}

Bu çalışmanın amacı Türkiye'nin en önemli kurumlarından olan Türkiye Cumhuriyeti Sağllk Bakanliğı örneğinde elektronik belge yönetim sisteminin (EBYS) kullanılabilirliğini değerlendirmektir. Çalışmada nicel ve nitel yöntem bir arada kullanılmıştır. EBYS'nin kullanılabilirliği görev tabanlı bir uygulamanın yanı sıra, sistem-kullanıcı etkileşimlerini değerlendirmeye odaklanan görüşmeler doğrultusunda analiz edilmiştir. Bulgular, katılımcıların TC Sağlık Bakanlı̆̆ EBYS'sini tatmin edici ve güvenilir bir sistem olarak değerlendirdiğini, bununla birlikte sistemin bazı zayıf yönleri olduğunu düşündüklerini göstermiştir. Katılımcılara göre ĕgitim videoları ve kullanıcı geri bildirimleri başta olmak üzere kullanılabilirliği artıracak bir takım iyileştirmeler kaçınılmaz görülmektedir. Alanyazına katkı sağlaması beklenen bu çalı̧̧ma sonunda ulaşılan vargıların, araştırmacılar ve sistem geliştiriciler için örnek bir EBYS - kullanıcı deneyimi ortaya koyacağı dü̈sünülmektedir.

Anahtar Sözcükler: Kullanılabilirlik; elektronik belge yönetim sistemi; Türkiye Cumhuriyeti Sağlık Bakanlı̆̆ EBYS.

\section{Introduction}

Usability is defined as a function of the ease of use of a product. In other words, usability means the effective usage of a product by a particular user for a particular task in a particular context (Bevan, Kirakowski, and Maissel, 1991). Usability studies became popular in the 1980s. Since

\footnotetext{
*Dr., Hacettepe University Department of Information Management, Turkey.

E-mail: semanuroztemiz@gmail.com

Dr., Hacettepe Üniversitesi Bilgi ve Belge Yönetimi Bölümü.
}

Received - Geliş Tarihi: 11.06.2019

Accepted - Kabul Tarihi: 09.12.2019 
then, they have increased heavily in investigating human-computer interaction (Lior, 2013, p. 268). Usability is indispensable for all types of use, no matter what they cover, and issues under its function have a significant effect on the purpose, independently from the field of application. If we think about computer systems, their enhancement on work productivity and pleasure, such as reduced error rates and increased cost savings, usability plays a vital role. (Ovaska, 1991, p. 47-48). In this study, usability is analyzed over ERMS, which is defined as "a computerized system that facilitates the creation, capture, organization, storage, retrieval, manipulation and carrying out of institutions' works and transactions within the framework of their legal obligations" (Özdemirci and Bayram, 2009; Yatin, Ramli, Hashim and Kadir, 2015). The system requirements, design features, security, and management have been subjected by many research related to ERMS. According to some researches, "an ideal ERMS should include a process for check-in check-out, version control and audit trail, record review, security processes, organizational processes, free-text searching, metadata, workflow, imaging, and publishing" (National Archives in Malaysia, 2011; Raynes, 2002). Adopting ERMS in all institutions and using electronic environments for exchanging official records between institutions, contribute to the expected development in the operation of organizational structures (Demirtel and Bayram, 2014).

Thanks to the capacity of ERMS to store original records, organizations prefer to benefit from ERMS, while digitizing and storing paper record collections (Brown, 1993; Tiitinen, Lyytikainen, Paivarinta, and Salminen, 2000; Hung, Tang, Chang, and Ke, 2009; Shepherd, 1994). ERMS manages only records, not the information contained within records. It provides efficiency in record storage and retrieval and information access (Yatin et al. 2015). ERMS provides a structure that enables production, distribution, and archiving of all record based archival materials produced in the enterprise. Several researchers emphasize that ERMS is primarily applied in archiving (Bikson and Frinking, 1994; Brown, 1993). Some of the studies directly mention the usability of ERMS. Su and his friends (2017) aimed to understand the usability of ERMS in state institutions using the benefits of human factor engineering. They recommended using human factor engineering for system interface design when setting up a record management system. Su and his friends also believed that the system helped to maintain efficiency and provided the main purpose of structuring withstanding record management systems in state institutions.

Some researches aimed to investigate the ERMS usage in their countries. Yatin and others (2015) revealed the factors that affect the usability and effectiveness of the record management system in public organizations in Malaysia. Results have shown that service quality and information quality are significantly correlated. This study provided valuable information for the government in implementing the "Generic Office Environment - Electronic Government Document Management System" in the future. Corrao and others (2010) initiated to examine the role of usability testing in the evaluation of an Electronic Health Record System. They detected general functionality but higher overall satisfaction than expected. As a result of their study, Corrao and others (2010) mentioned that usability testing could improve the chances that enable to design of ERMS in an integrated way with existing workflow and business processes. Gregory (2005) investigated the implementation of an ERMS in the National Health Service Purchasing and Supply Agency, a UK government agency. This study shows that ERMS causes a massive cultural shift that can be made easier with the backing of senior management. In his study Gregory (2005) also emphasizes that desired results can be achieved with a strong team. Johnston and Bowen (2005) revealed the benefits achieved by organizations that have implemented an ERMS. This research claimed that an organization that is planning to implement an ERMS could be confident that ERMS provides real benefits and an acceptable return on investment.

In Turkey, though usability-focused studies are few, the literature on ERMS is quite extensive. Studies are examined the subject both in terms of its theoretical aspects and in terms 
of its application. Tamtürk (2017) examined the benefits of ERMS that would be provided to the public. In line with this objective, Tamtürk evaluated the concept of e-government, and he investigated frequently encountered problems and solutions for system development. Karagöz (2013) examined the usability of the ERMS of Middle East Technical University. He identified some usability issues such as complexity and inconsistency as a result of his study. He suggested that the home page of the system should be designed for easy to use and the actions. In his study Külcü (2009a) evaluated new aspects of records management practices introduced by the start of the provision of public services in the electronic environment. He emphasized the requirements of legal and administrative criteria related to ERMS applications. In another study, Külcü (2009b) assessed the records system of a Turkish public university, using the example of Hacettepe University to develop records management programs in Turkish universities. He determined that institutional processes in Turkish public universities relating to records were not able to meet legal and administrative requirements. Yalçınkaya (2016) analyzed the factors that contribute to the successful implementation of ERMS by organizations and the benefits gained through ERMS implementation. He mentioned that a successful benefit analysis should contain details about organizations, staff, society, financial, and environmental. Özdemirci and Bayram (2009) aimed to introduce the basics of national records management and to direct a policy that will provide speed and function to the integrated state structure within the public. The researchers mentioned that an e-government transformation working with national e-record management policy can enable the creation of a public administrative structure with an effective, transparent and simplified business process, and can provide better quality and faster public service to the business world.

There is not a standard ERMS implementation in the public institutions in Turkey. In other words, ERMS implementations are differently shaped based on institutional requirements. This study will help to understand the usability of the ERMS in the case of the Ministry of Health. From the viewpoint of the Ministry of Health, ERMS is a kind of system which records any document created by its central, provincial and abroad organizations and associated and affiliated institutions' organizations, and shares that information within electronic media and provides easy access to ERMS users (Republic of Turkey Ministry of Health Annual Report, 2018, p. 22). "Ministry of Health ERMS is amongst the commonly used system by a large number of users (220000 users). Also, there is no other institution widely using this system concerning provincial organizations. In fact, in addition to central institutions and affiliated departments, ERMS is widely used by all health departments from the 81 cities of Turkey, and generated document quantity goes up to 12 million in those departments. By taking into account user and document counts, it can be said that the Ministry of Health is the most widely ERMS used institution in Turkey" D. Kavak (personal communication, November 25, 2019) ${ }^{1}$.

Usability is based on user feedback through evaluation rather than relying on the designer's experience and background. This study can be useful to reveal the usability of ERMS of the Ministry of Health in users' points of view. Research findings can be useful in the improvement process of the system effectively.

\section{ERMS in Turkey}

The beginning of ERMS in public institutions of Turkey dates back to the 2000s when arrangements of transporting work processes to electronic media were being carried out. Standardization activities were performed to overcome differences arisen in institutional applications, based on international samples in 2003 (Kandur, 2011).

\footnotetext{
${ }^{1}$ This information was obtained from Health Specialist Dilek Kavak, Unit Supervisor of the ERMS of Ministry of Health. The interview held on November 25, 2019.
} 
In 2003, important steps were taken to actualize the e-Turkey Project, which was aimed to comply with global competitive conditions and to protect the integrity of all activities in this field by determining information society strategy and politics in the supervision of General Directorate of State Archives ("Yüksek Planlama Kurulu", 2005). The process, in which Marmara University Department of Information Management was also involved, had been completed right after necessary arrangements on editing and accessing records.

"e-signature law," which come into force in 2004, 23rd of July, made records generated in electronic media to be valid legally (Önaçan, 2012). By the General Directorate of State Archives, the first model named "Electronic Records Management System Criteria Reference Model (v.1.0)" covering ERMS's legal, technical and administrative aspects was released. In 2006 a more sophisticated version of the model was released (Kandur, 2011).

In Turkey, public institutions and organizations initiated the use of electronic record generating and management in a widespread manner beginning from 2007. In the same year, "TS 13298 Electronic Records Management Standard" was issued by modeling ISO 15489 Information and Documentation - Records Management ( ${ }^{\text {nd }}$ part) standard on and became a mandatory standard in public institutions (Kandur, 2011; Özdemirci, 2003).

In 2011, by a series of legal arrangements, the first steps were taken for the Registered Electronic Mail (REM) system, which provides secure and efficient record exchange between public institutions and organizations and supports legal validity to those records (Özaçan, 2012).

The latest version of the TS 13298 standard, which was first developed and released in 2015, also emphasizes record sharing between institutions. It was proposed ERMS in institutions and organizations to work together with other information systems in an integrated manner (Kandur, 2016). The regulation on procedures and principles required by official correspondences, which came into force in 2015, made it obligatory for public institutions and organizations officially to communicate under e-Correspondence Project, to conform to the eCorrespondence Technical Guide prepared by Ministry of Development (Tahtalığlu, 2018).

\section{Methodology}

This study was conducted using a mixed-method. The term "mixed method" refers to the integration of quantitative and qualitative data within a single investigation. The main feature of this methodology is that such integration allows the use of more complete and synergistic data than performing separate quantitative and qualitative data collection and analysis (Wisdom and Creswell, 2013).

The time spending on task and counting of mouse clicks are among the most common measures in the evaluation of usability (Kortum and Acemyan, 2016). In the first stage of this study, a task-based usability test implemented to volunteers from the General Directorate of Health Information Systems Department, which has the most common users of ERMS in the Ministry of Health. General Directorate of Health Information Systems Department has 13 staff, and 10 of them were volunteers for attending to the study. Participants (P) were composed of help desk officers (P1 and P2), consultants (P3 and P5), health specialists (P4 and P10), assistant specialists (P6 and P7) and test specialists (P8 and P9). While selecting participants, age, sex, educational background, computer, and internet skill levels are not taken into consideration.

To carry out the research, the functions of ERMS were determined, and 10 tasks were prepared to measure users' 'task perform'. The ERMS unit supervisor was consulted in determining the tasks. An appropriate research environment was prepared, and participants were asked to perform tasks. The records of the click counts and access times were kept by the Camtasia Studio program, while the SPSS program was used for the analysis of these data. The participants have been informed that in any case, they are not allowed to ask for assistance, as it 
would damage the overall accuracy of the research. It was also stated that any question they fail to answer could be skipped. The research was carried out in a quiet and natural environment where the participants can feel relaxed.

Usability can't be analyzed by just counting clicks or time spent. The user's positive experience and task completion skills should be the key metrics for measuring usability (Farley, 2017). Therefore, in the last stage, an interview with semi-structured questions was conducted with participants to assess their satisfaction with the system. Collected data through interviews were analyzed using the content analysis method. In this context, data coded and interpreted under appropriate themes. Then these data have been analyzed, interpreted, and added to report.

\section{Findings}

All of the participants were experienced with ERMS. The task scenarios, which users were required to complete as follows:

Task 1: Create a record on the subject of stethoscope requests for health personnel using the new draft method.

Task 2: Create a record related to the security demands of doctors with the draft method from the file.

Task 3: Protect the record that is related to the health system in the hospitals of Turkey.

Task 4: Send the record related to participation in a conference on preventing obesity in Turkey to the General Directorate of Health Services.

Task 5: Send the down syndrome information meeting record to the Director of General Public Health.

Task 6: Answer a record which is about health literacy in public administration.

Task 7: Send the same record, which is about ERMS installation and usage information, to ERMS director, to archives, and helpdesk.

Task 8. Re-circulating a record to someone else. The record related to joining a symposium on a healthy life. Send it to the ERMS director to invite him. Then re-arrange the same record and send it to the information manager.

Task 9. Automatically print the record on routine monthly meeting with the related button in the "Topic, Privacy, File Plan and Distribution" metadata fields in the new draft template.

Task 10. Automatically print "Distribution, Flow, Attachment, and Interests" metadata fields in the new draft template with the relevant buttons.

The number of clicks for completing a particular task and task completion time defined as quantitative findings. These findings, which derived from completing state of users on 10 tasks, are listed below.

Table 1 identifies the completion of the tasks for each user; also, it shows the accomplishment state of the tasks. According to The ISO/IEC 9126-4 Standard metrics (2004), the task completion rate is between $80 \%-100 \%$ (Number of tasks completed successfully/total number of tasks undertaken $\mathrm{x} 100 \%$ ). Based on this finding, it can be said that the effectiveness of the system is very high. All of the participants accomplished tasks between 1 and 4 and task 8. P5 was the only participant who could not complete task 5. P4 was unsuccessful for T6 and T7. Assistant specialists (P6 and P7) could not perform T9 and T10. The participants also stated their opinions on many different aspects of the ERMS throughout the usability test. Most of the opinions indicate their satisfaction with the system.

Task completion time is seen as an important criterion for an effective system. Short completion durations foster higher perceived trustworthiness and lower user frustration (Ceaparu 
et al. 2004; Nielsen, 1999). Long completion duration may cause lower satisfaction and poor productivity (Hoxmeier and DiCesare, 2000). Table 2 shows the completion duration for each task in minutes. It shows that the completion times are generally similar, but that the tasks between T5 and T10 are completed in longer duration. The higher completion times can be a result of the tasks that require more effort or the wrong choice of participants. The participants may also have chosen the longest path in the system. If they had chosen the lowest path, they would have completed the tasks in less time.

Table 1

Task completion state

\begin{tabular}{|c|c|c|c|c|c|c|c|c|c|c|c|c|}
\hline \multirow[b]{2}{*}{ Tasks (T) } & \multicolumn{10}{|c|}{ Participants (P) } & \multirow[b]{2}{*}{ Successful } & \multirow[b]{2}{*}{ Unsuccessful } \\
\hline & $\mathrm{P} 1$ & $\mathrm{P} 2$ & $\mathrm{P} 3$ & $\mathrm{P} 4$ & P5 & P6 & P7 & P8 & P9 & P10 & & \\
\hline $\mathrm{T} 1$ & $\sqrt{ }$ & $\sqrt{ }$ & $\sqrt{ }$ & $\sqrt{ }$ & $\sqrt{ }$ & $\sqrt{ }$ & $\sqrt{ }$ & $\sqrt{ }$ & $\sqrt{ }$ & $\sqrt{ }$ & 10 & 0 \\
\hline $\mathrm{T} 2$ & $\sqrt{ }$ & $\sqrt{ }$ & $\sqrt{ }$ & $\sqrt{ }$ & $\sqrt{ }$ & $\sqrt{ }$ & $\sqrt{ }$ & $\sqrt{ }$ & $\sqrt{ }$ & $\sqrt{ }$ & 10 & 0 \\
\hline T3 & $\sqrt{ }$ & $\sqrt{ }$ & $\sqrt{ }$ & $\sqrt{ }$ & $\sqrt{ }$ & $\sqrt{ }$ & $\sqrt{ }$ & $\sqrt{ }$ & $\sqrt{ }$ & $\sqrt{ }$ & 10 & 0 \\
\hline $\mathrm{T} 4$ & $\sqrt{ }$ & $\sqrt{ }$ & $\sqrt{ }$ & $\sqrt{ }$ & $\sqrt{ }$ & $\sqrt{ }$ & $\sqrt{ }$ & $\sqrt{ }$ & $\sqrt{ }$ & $\sqrt{ }$ & 10 & 0 \\
\hline T5 & $\sqrt{ }$ & $\sqrt{ }$ & $\sqrt{ }$ & $\sqrt{ }$ & $\mathrm{X}$ & $\sqrt{ }$ & $\sqrt{ }$ & $\sqrt{ }$ & $\sqrt{ }$ & $\sqrt{ }$ & 9 & 1 \\
\hline T6 & $\sqrt{ }$ & $\sqrt{ }$ & $\sqrt{ }$ & $\mathrm{X}$ & $\sqrt{ }$ & $\sqrt{ }$ & $\sqrt{ }$ & $\sqrt{ }$ & $\sqrt{ }$ & $X$ & 8 & 2 \\
\hline T7 & $\sqrt{ }$ & $\sqrt{ }$ & $\sqrt{ }$ & $\mathrm{X}$ & $\mathrm{X}$ & $\sqrt{ }$ & $\sqrt{ }$ & $\sqrt{ }$ & $\sqrt{ }$ & $\sqrt{ }$ & 8 & 2 \\
\hline T8 & $\sqrt{ }$ & $\sqrt{ }$ & $\sqrt{ }$ & $\sqrt{ }$ & $\sqrt{ }$ & $\sqrt{ }$ & $\sqrt{ }$ & $\sqrt{ }$ & $\sqrt{ }$ & $\sqrt{ }$ & 10 & 0 \\
\hline T9 & $\sqrt{ }$ & $\sqrt{ }$ & $\sqrt{ }$ & $\sqrt{ }$ & $\sqrt{ }$ & $X$ & X & $\sqrt{ }$ & $\sqrt{ }$ & $\sqrt{ }$ & 8 & 2 \\
\hline $\mathrm{T} 10$ & $\sqrt{ }$ & $\sqrt{ }$ & $\sqrt{ }$ & $\sqrt{ }$ & $\sqrt{ }$ & $X$ & $X$ & $\sqrt{ }$ & $\sqrt{ }$ & $\sqrt{ }$ & 8 & 2 \\
\hline $\begin{array}{l}\text { Task completion } \\
\text { rate }(\%)\end{array}$ & 100 & 100 & 100 & 80 & 80 & 80 & 80 & 100 & 100 & 90 & & \\
\hline
\end{tabular}

Table 2

Task completion time (by minutes)

\begin{tabular}{|c|c|c|c|c|c|c|c|c|c|c|c|c|c|}
\hline \multirow[b]{2}{*}{ Tasks $(\mathrm{T})$} & \multicolumn{8}{|c|}{ Participants $(\mathrm{P})$} & \multicolumn{5}{|c|}{ Time } \\
\hline & P1 & P2 & P3 & P4 & P5 & P6 & P7 & P8 & P9 & P10 & Min. & Max. & Avg. \\
\hline $\mathrm{T} 1$ & 01:06 & $01: 35$ & $02: 12$ & $02: 13$ & 02:01 & 02:11 & $01: 20$ & $02: 17$ & $02: 14$ & 02:01 & 01:06 & 02:17 & $01: 55$ \\
\hline $\mathrm{T} 2$ & $02: 10$ & 01:08 & 02:03 & 02:01 & $01: 48$ & $01: 10$ & 01:02 & 02:02 & $01: 49$ & $01: 52$ & 01:02 & $02: 10$ & $01: 42$ \\
\hline T3 & $00: 40$ & $00: 43$ & $00: 45$ & $00: 47$ & $00: 46$ & $00: 41$ & $00: 38$ & $00: 58$ & $00: 57$ & $00: 49$ & $00: 38$ & $00: 58$ & $00: 46$ \\
\hline $\mathrm{T} 4$ & $00: 59$ & 01:06 & $01: 48$ & $02: 10$ & 02:03 & $01: 13$ & 01:21 & $01: 48$ & $01: 26$ & $02: 12$ & $00: 59$ & $02: 12$ & $01: 36$ \\
\hline T5 & $02: 45$ & $02: 37$ & $02: 51$ & $02: 16$ & & $02: 48$ & 03:10 & $02: 11$ & $02: 49$ & $02: 29$ & $02: 11$ & $03: 10$ & $02: 39$ \\
\hline T6 & $03: 10$ & $02: 48$ & $02: 51$ & - & $02: 44$ & $02: 38$ & $02: 39$ & $02: 47$ & $02: 38$ & - & $02: 38$ & $03: 10$ & $02: 46$ \\
\hline $\mathrm{T} 7$ & $02: 45$ & $02: 33$ & $02: 41$ & - & & $02: 29$ & $02: 12$ & $02: 24$ & $02: 12$ & 02:37 & $02: 12$ & $02: 45$ & $02: 29$ \\
\hline $\mathrm{T} 8$ & & $02: 49$ & 03:01 & 3:04 & $02: 57$ & $02: 49$ & $02: 48$ & $02: 57$ & $02: 32$ & $02: 44$ & $01: 12$ & 03:04 & $02: 41$ \\
\hline T9 & $02: 22$ & $02: 32$ & $02: 18$ & 03:06 & $02: 42$ & 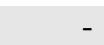 & & $02: 32$ & 02:41 & 02:27 & $02: 18$ & 03:06 & $02: 35$ \\
\hline T10 & $02: 13$ & $02: 11$ & $02: 34$ & $02: 10$ & $02: 24$ & - & - & $02: 47$ & $02: 36$ & $02: 24$ & $02: 10$ & $02: 47$ & $02: 24$ \\
\hline Total & $19: 22$ & $20: 02$ & 23:04 & $17: 47$ & $17: 25$ & $15: 59$ & $15: 10$ & $22: 43$ & $21: 54$ & $19: 35$ & & & \\
\hline
\end{tabular}

When the longest and lowest completion durations are compared in Table 2, it is observed that the difference is higher in T8. The shortest completion duration is one minute and 12 seconds, while the longest completion time is 3 minutes and 4 seconds. The difference can be thought to be due to user experiences or features. This situation can be identified with different factors such as age, experience, and excitement level. When considering the completion time for the participants, it is seen that the P3 spent less time to complete the tasks. In general, participants spent less time on ERMS for protecting the record that is related to the health system (T3), while they spent more time on answering a task which is about health literacy (T6).

Click counts is one of the most common measures in the evaluation of usability (Kortum and Acemyan, 2016). The common known three-click rule is an unofficial rule concerning the design of systems navigation. It suggests that a user should be able to find any information with no more than three mouse clicks, although there is little empirical evidence to demonstrate the validity of the three-click rule, optimal clicks make users more willing to use a system (Iglesias, Paredes, Gomez and Gutierrez, 2018). 
Table 3

Distribution of click counts for each task

\begin{tabular}{|c|c|c|c|c|c|c|c|c|c|c|c|c|c|c|}
\hline \multirow[b]{2}{*}{ Tasks (T) } & \multicolumn{9}{|c|}{ Participants } & \multicolumn{4}{|c|}{ Click Counts } & \multirow{2}{*}{$\frac{\text { Optimal Path }}{\text { Counts }}$} \\
\hline & P1 & P2 & P3 & P4 & P5 & P6 & P7 & P8 & P9 & P10 & Min. & Max. & Avg. & \\
\hline $\mathrm{T} 1$ & 13 & 19 & 16 & 17 & 14 & 16 & 15 & 18 & 18 & 20 & 13 & 20 & 17 & 12 \\
\hline $\mathrm{T} 2$ & 12 & 9 & 11 & 11 & 24 & 11 & 10 & 11 & 12 & 11 & 9 & 24 & 12 & 10 \\
\hline $\mathrm{T} 3$ & 14 & 11 & 11 & 11 & 12 & 11 & 10 & 11 & 12 & 11 & 10 & 14 & 11 & 8 \\
\hline $\mathrm{T} 4$ & 11 & 11 & 11 & 11 & 21 & 11 & 10 & 11 & 10 & 11 & 10 & 21 & 12 & 9 \\
\hline T5 & 27 & 28 & 25 & 25 & 23 & 29 & 31 & 27 & 24 & 29 & 23 & 31 & 27 & 19 \\
\hline T6 & 27 & 41 & 24 & - & 23 & 36 & 39 & 33 & 33 & - & 23 & 41 & 32 & 19 \\
\hline $\mathrm{T} 7$ & 25 & 26 & 28 & - & - & 24 & 25 & 25 & 25 & 23 & 23 & 28 & 25 & 21 \\
\hline $\mathrm{T} 8$ & 24 & 34 & 31 & 26 & 22 & 30 & 32 & 26 & 25 & 28 & 22 & 34 & 28 & 20 \\
\hline T9 & 27 & 28 & 24 & 24 & 22 & - & - & 21 & 23 & 25 & 21 & 28 & 24 & 18 \\
\hline T10 & 34 & 36 & 32 & 33 & 34 & - & - & 27 & 26 & 32 & 26 & 36 & 32 & 23 \\
\hline Total & 214 & 243 & 213 & 158 & 195 & 168 & 172 & 210 & 208 & 190 & 158 & 243 & 197 & 88 \\
\hline
\end{tabular}

It can be seen from Table 3 that participants clicked more for the tasks T5 - T10. Users made far fewer mouse clicks on tasks on which they answered more quickly. The task T6, regarding answering a record which is about health literacy had shown a higher number of clicks (on average 32 times), while the task T3, about protecting the record that is related to health system had been clicked less (on average 11 times). When participants compared concerning click numbers, it is seen that the P2 (a help desk officer) clicked more than other participants did. P1, who is a health specialist, is the second-most clicker. The two most clicker participants are from different status. However, P8 and P9 are both testing specialists; they have close click counts (210 and 208, respectively). Thus, it can be said that status is not a determinative factor on the click counts. In all tasks, click counts of the participants are much more than the click counts of the shortest path suggested by the system. These differences especially have been observed during the completion of T6 - T8, and T10.

\section{The Views of the Participants about ERMS}

In the last stage of the study, an interview with the semi-structured questions was conducted to learn users' opinions concerning the ERMS. Research data were analyzed by the content analysis method. In the content analysis, research data was coded and analyzed under the concepts that explain them (Yıldırım and Şimşek, 2000). In this study, the data obtained from interviews were explained under five themes (see Table 4) coded by pre-determined concepts. The research process was completed after the findings were interpreted. 
Table 4

Research themes

\begin{tabular}{ll}
\hline Themes & \\
\hline Benefits of ERMS & How ERMS affect the period of record generation? \\
ERMS usage features & How has ERMS affected the record submission process? \\
& How do you evaluate ERMS usage? \\
& Do you need someone else's support in using ERMS? \\
& Do you prefer Web application? \\
& Does it support mobile applications? \\
ERMS help and navigation & What are the help options? \\
& Are the help options sufficient? \\
& How often do you refer to the help record when using ERMS? \\
& What does the system direct the user to? \\
& Are there any navigation options? \\
Learnable and memorable & Is the system easy to learn? \\
& Are the features of the system memorable? \\
The weakness and strengths of the system & What are the developing aspects of the system? \\
\end{tabular}

Benefits of ERMS

Under this theme, participants have evaluated the effects of ERMS on the period of record generation and record submission. All of the participants have claimed that the record management process has been shortened and facilitated by using ERMS.

"If you try to set the format in a paper, it will take at least 15-20 minutes. ERMS provides direct progress through the existing template. This situation has a positive effect on saving time" (P1).

"A user saves the average half an hour for a standard record by using ERMS. The system leads the user to be practical and fast. It also prevents paper waste" (P2).

"When a record distributes all over Turkey, it takes too much time. It takes a minimum of five minutes. However, the longest post in ERMS takes only 2 minutes. Although personal skills play an important role in this process, the time difference may be as low as 1/10 compared to physical record distribution" (P3).

"It takes quite a long time to find envelopes, addresses, and interested persons during the record sending process. ERMS certainly takes less time to generate records." (P4).

It is thought that ERMS minimizes the risks related to the record management process.

"The record distribution process in the physical environment had many difficulties. It was quite time-consuming to search an envelope to send the record physically. Risks based on bureaucratic processes (such as losing time and effort, forcing physical damage to the record, accessing records by unauthorized persons, etc.) may exemplify these difficulties" (P5).

It is particularly emphasized that ERMS provides low-cost advantage and eliminates repetitive business processes.

"I want to draw attention to the benefits of ERMS in terms of cost. It reduces the cost of distribution. In a physical distribution environment, you may be awaiting a response for a record that does not reach its recipient. However, you are now able to see who receives and reads the records in ERMS" (P5).

"The attachment of the record arrives later when records are arranged in a physical environment. In contrast, ERMS brings them together" (P6). 


\section{ERMS Usage Features}

Within the scope of this theme, it is aimed to evaluate the utilization features of ERMS. In this context, the participants were asked some questions such as ease of use, language features, web, and mobile applications of ERMS. All of the participants pointed out that the system has easyto-use features. It also has satisfying visual elements.

"A user who does not know about the system does not need any explanation by experts and other knowing people after the training process. The system is already directing the user to write in the correct format and automatically complies with the official correspondence rules. I do not prefer web application. I support mobile applications and use them periodically" (P1).

"Easy to use. I do not need anybody's support. The visual features are well designed" (P2).

'Its' usage is quite easy, considering the ERMS of different institutions. I do not need the support of someone in use. It's quite easy to generate or send a record on the system. I prefer web application from time to time. I am using mobile app. The visual features are quite developed" (P3).

"ERMS of Ministry of Health is a user-friendly system. I use the web application only in emergencies. I know it supports mobile applications, but I have not used it. The colors, points, menu items are extremely well designed" (P4).

"It's usage is quite easy, considering the ERMS of different institutions. I prefer web application. I have not downloaded the mobile app to my phone due to security reasons" (P5).

"I need the support of someone else, such as removing a file, saving an incoming record, etc." (P6).

"For effective use, public culture should also be known. The system leads the user to this understanding. Mobile applications would use to see records in case of an emergency." (P7).

"I love using mobile applications because they're easy to use" (P9).

"I prefer web and mobile applications" (P10).

ERMS Help and Navigation

Under this theme, the participants were asked to evaluate the help and navigation features of ERMS. Help options and navigation features were evaluated within the framework of their sufficient. Participants have satisfied the help and navigation features.

"I never used the help record. Help options include software support, help record in the ERMS, phone, etc. Help options are quite enough. Navigation options are also adequate" (P1).

"I do not need the help record. Help options include help records and videos. Help options are adequate for me" (P2).

"Help options: help record on the port, phone, and software support. Help options are more than adequate. Users are smart. They do what the system administrators cannot think of. The active use of the distribution area is lovely, and this record provides a great advantage in sending. With the right to use, the system does not like the less. Navigation options are sufficient" (P3).

"Help options are quite enough. They are satisfying for a user" (P4).

"Navigation options are sufficient; I get warnings in possible shortcomings or wrong choices. Thanks to warnings, I can see my errors and complete the missing fields" (P6). 
"The system warnings and notes are sufficient in the navigation options" (P9).

\section{Learnable and Memorable Features}

Participants were asked to evaluate systems related to learnability and memorable features. All of the participants indicated that they had found the system very easy to use, and accessing features easy to memorize.

"The system is quite easy to learn. What you learn remains in your mind. Even the middle age people from the provincial organization can easily remember the system's features. If they forget something, the help record is already very practical to solve the problem" (P1).

"The system is exactly learnable and memorable. The system's shortcomings: the outgoing folder is complex; the more irrelevant results are coming when looking for records. The answer does not exactly serve." (P3).

The Weaknesses and Strengths of the System

Under this theme, the weak and strong aspects of the system were evaluated. Most of the participants have indicated that they encountered no error in the system. They see it quite enough, safe, fast, time, or platform-independent and practical.

"I think the system is quite enough, and it does not need to be improved. Strengths aspects of the system are reliable, by rules and fast" (P1).

"The system has enough options for its users. Strengths aspects of the system can be expressed as safe, fast, practical, independent of time and space" (P2).

"Strengths: I have access to records on many platforms that are independent of time and space. Paraph, mobile signature, and e-signature support in the mobile environment is a huge plus. The system stops wasting paper and filing. There is a simple archiving (filing) logic. A record association exists. The 5070 supports electronic signature law and many other regulations. It provides ease of sending records to institutions and organizations using Registered Electronic Mail. There is no situation concerning the end-user in the submission of REM, the general record that provides automatic transmission in the department" (P3).

"The strengths of the system: Safe, fast, problem solver (for damages such as loss and delay)" (P4).

"Strengths: providing hierarchical control, it's safer than physical way, saves time-cost, it positively affects our corporate image." (P5).

"The strengths of the system: fast, prevent record loss, easy accessibility. It also provides hierarchical order" (P6).

"E-mail integration is nice. One-click is enough to send the record by e-mail. I can easily export a barcode record. Improvements can be made for the end-user for reporting" (P7).

"The strengths of the system are to be safe and fast. These are very important features for us" (P9).

It is expected that the system should contain more detail in some applications. However, some help videos may be kept shorter.

"The outgoing folder is complex; the more irrelevant results are coming when looking for records. The answer option does not serve satisfying" (P3).

"Weaknesses: More details on Standard File Plans (SFPs) can be shared. There may also be more explanatory information about the SFP in the removal of the record. There is a need for training on how to search the record." (P4). 
"Help videos can be kept shorter; less is more. Each topic in ERMS can be considered as a different video headline. Long videos do not track users. Directions to improve the system: It must include more informative videos. Because it is an official application, the user has a timid approach for using it." (P5).

It is thought that the system can be improved with some add-ons or revisal.

"Tracking option can be added to the system. For example, users from the same department should have the option to view any record." (P6).

"The over script, the attachment, and the interest can be sent by only one process. It is time-consuming to prepare and follow in the physical environment. The system leads users to adapt to the correct hierarchical flow, formal correspondence rules, and other standards." (P10).

\section{Conclusion}

This study investigated the usage and effectiveness of the record management system in the Republic of Turkey Ministry of Health, which is a public regulatory institution in the field of health. The participants supported the research with two-stage participation. In the first phase of the study, the participants asked to fulfill the predetermined tasks. In the next stage, they were asked to evaluate the system within the framework of various aspects.

Findings show that most of the participants completed all tasks successfully. Findings also indicate that the system is quite effective in terms of usability. For most of the participants, the system has satisfactory features. According to the participants, the most known features of the system are reliable and fast. Language, visual features, and menu options were defined as functional and convenient. Participants evaluated the access features of the system as easy to remember. The multiple options for access can be seen among the satisfying features of the system. The intense use of the web or mobile application options is among the supportive findings. The practicality of integrated services such as email integration is pleasing for users.

Research findings also showed that the system minimizes hierarchical error in record submission. The record management process has been shortened and facilitated by using ERMS. Usefulness, ease of use, help, and navigation options are important for users' intention to use ERMS. The use of ERMS provides many advantages such as increasing worker efficiency, improving services, increasing record storage capacity, and eliminating duplication of work by different departments. On the other hand, some incomplete features are giving less detail for using the main elements, such as the Standard File Plan. Besides, there is a need for training in performing searches in the system. Existing training videos are seen as not satisfactory but also time-consuming. The findings of the study yield actionable results that positive impact on existing ERMS performance. Therefore, the results should be considered in light of the objectives and goals of the institution. Some suggestions can be taken into consideration, based on the obtained findings below:

- Training videos should contain more practical information.

- The system must not waste the user's time.

- Some buttons can handle the user feedback mechanism.

- Record tracking options can be expanded to allow the same record to be viewed by all concerned.

- The search results screen should be organized to bring more meaningful results.

- The usability test should be carried out again.

- The system should be revised using findings

- More work could be carried out on the usability of ERMS. 
- Some future researches may include comparisons with other institutions or other countries.

It is hoped that research in this area will continue, and each discovery will improve and perfect the measurement and evaluation of ERMS' effectiveness.

\section{Acknowledgment}

I would like to thank Health Specialist Dilek Kavak for her contribution to the data collection process.

\section{References}

Bevan, N., Kirakowski, J., and Maissel, J. (1991). What is usability? Available at https://pdfs.semanticscholar.org/6ebb/47bcbe8fbe3f427fef4c0ecb3235e206d15d.pdf

Bikson, T. K. (1994). Organizational trends and electronic media: work in progress. The American Archivist, 57(1), 48-68.

Brown, T. E. (1993). A decade of development: Educational programs for automated records and techniques within the Society of American Archivists. American Archivist, 56(3), 410-423. doi:10.17723/aarc.56.3.3302282246h65268

Ceaparu, I., Lazar, J., Bessiere, K., Robinson, J., and Shneiderman, B. (2004). Determining causes and severity of end-user frustration. Available at http://www.cs.umd.edu/hcil/trs/2002-11/200211.pdf

Corrao, N. J., Robinson, A. G., Swiernik, M. A. and Naeim, A. (2010). Importance of testing for usability when selecting and implementing an electronic health or medical record system. Journal of Oncology Practice, 6(3), 120-124. Available at https://www.ncbi.nlm.nih.gov/pmc/articles/PMC2868635/

Demirtel, H., and Bayram, Ö. (2014). Elektronik belge yönetim sistemlerinin verimliliğe katkısı: Kalkınma Bakanlığı örneği. Bilgi Dünyası, 15(1), 91-101. Available at http://bd.org.tr/index.php/bd/article/view/423

Farley, M. (2017). 4 reasons why counting clicks is overrated. Available at https://cetaris.com/blog/4 reasons-counting-clicks

Gregory, K. (2005). Implementing an electronic records management system: A public sector case study. Records Management Journal, 15(2), 80-85. doi:10.1108/09565690510614229

Hoxmeier, J. A., and DiCesare, C. (2000). System response time and user satisfaction: an experimental study of browser-based applications. M. Chung (Ed.), In Proceedings of the 6th Americas Conference on Information Systems (p. 140-145). Long Beach, CA. Available at http://citeseerx.ist.psu.edu/viewdoc/download?doi=10.1.1.99.2770\&rep=rep1\&type=pdf

Hung, S. Y., Tang, K. Z., Chang, C. M., and Ke, C. D. (2009). User acceptance of intergovernmental services: An example of electronic document management system. Government Information Quarterly, 26(2), 387-397. Available at https://www.sciencedirect.com/science/article/pii/S0740624X08001627

Iglesias, L. J., Paredes, C. A., Gomez, L. S., and Gutierrez, M. P. M. (2018). User experience and the media: The three-click rule on newspaper websites for smartphones. Available at http://www.revistalatinacs.org/073paper/1271/RLCS-paper1271en.pdf

Johnston, G. P., and Bowen, D. V. (2005). The benefits of electronic records management systems: a general review of published and some unpublished cases. Records Management Journal, 15(3), 131-140. doi:10.1108/09565690510632319

Kandur, H. (2011). Türkiye'de kamu kurumlarında elektronik belge yönetimi: mevcut durum analizi ve farkındalığın artııılması çalışmaları. Bilgi Dünyası, 12(1), 2-12. Available at http://bd.org.tr/index.php/bd/article/view/6

Kandur, H. (2016). Kamu kurumlarında elektronik belge yönetimi: güncel sorunlar ve geleceğe yönelik beklentiler. F. Özdemirci, N. Özel, T. Çakmak, Z. Akdoğan and Yalçınkaya (Ed.), In e-Beyas 
2015 Sempozyumu Kurumsal Belleklerin Geleceği: Dijitalleştirme-Elektronik Arşiv-Elektronik Belge Yönetimi (p. 29-34). Ankara, Ankara Üniversitesi Belge Yönetim ve Arşiv Sistemi Koordinatörlüğü. Available at http://2015.ebeyas.org/wp-content/uploads/2016/04/eBEYAS2015_Bildiriler.pdf

Karagöz, A. (2013). A usability study on electronic document management system in Middle East Technical University (Unpublished master thesis). Middle East Technical University: Ankara. Available at http://etd.lib.metu.edu.tr/upload/12616524/index.pdf

Kortum, P., and Acemyan, C. Z. (2016). The relationship between user mouse-based performance and subjective usability assessments. Available at https://journals.sagepub.com/doi/abs/10.1177/1541931213601275

Külcü, Ö. (2009a). Evolution of the e-records management practices in e-government: reflections from Turkey. The Electronic Library, 27(6), 999-1009. Available at http://www.bby.hacettepe.edu.tr/yayinlar/dosyalar/Evolution_of.pdf

Külcü, Ö. (2009b). Quality documentation and records management: A survey of Turkish universities. Aslib Proceedings, 61(6), 459-473. Available at https://www.emeraldinsight.com/doi/abs/10.1108/00012530910989616

Lior, L. N. (2013). Evaluating your information experience. In Writing for interaction: Crafting the Information Experience for Webb and Software Apps (p. 241-261). USA: Elsevier. Available at https://www.sciencedirect.com/science/article/pii/B9780123948137000122

Republic of Turkey Ministry of Health Annual Report. (2018). Available at https://sgb.saglik.gov.tr/Dkmanlar/TC\%20Sağlık\%20Bakanlığı\%20Faaliyet\%20Raporu\%202 18.pdf

National Archives in Malaysia (2011). Electronic records management systems -system specifications for public offices. Available at http://www.jpm.gov.my/sites/default/files/u290/ELECTRONIC\%20RECORDS\%20MANAGE MNT\%20SYSTEMS\%20-\%20SYSTEMS\%20SPECIFICATION.pdf

Nielsen, J. (1999). Trust or bust: Communicating trustworthiness in web design. Available at https://www.nngroup.com/articles/trustworthy-design/

Ovaska, S. (1991). Usability as a goal for the design of computer systems. Scandinavian Journal of Information Systems, 3, 47-62. Available at https://pdfs.semanticscholar.org/8594/d5e5ea801d4aa1d5a85f40b73cb3e6a4bb15.pdf

Önaçan, M. B. K. (2012). Kamu kurumları arasında elektronik belge alışverişi ile ilgili mevzuat ve kamu kurumlarında yapılması gerekenler. Bilgi Dünyası, 13(2), 494-506. Available at http://bd.org.tr/index.php/bd/article/view/81

Özdemirci, F. (2003). İlk uluslararası belge yönetim standardı: ülkemiz açısından bir değerlendirme. Türk Kütüphaneciliği, 17(3), 225-246. Available at http://www.tk.org.tr/index.php/TK/article/view/264

Özdemirci, F., and Bayram, Ö. (2009). Approaches of e-records management in e-state transformation process in Turkey. In Lytras M.D., Ordonez de Pablos P., Damiani E., Avison D., Naeve A., Horner D.G. (Ed.), Best Practices for the Knowledge Society. Knowledge, Learning, Development and Technology for All. WSKS 2009. Communications in Computer and Information Science, 49, 395-403. Springer, Berlin, Heidelberg. Available at https://link.springer.com/chapter/10.1007/978-3-642-04757-2_42

Su, T. J., Wang, S. M., Chen, Y. F., Tsou, T. Y., and Cheng, J. C. (2017). Investigating the usability of electronic records management systems in government organizations from a human factor engineering perspective. Journal of Advanced Management Science, 5(1), 14-18. Available at https://pdfs.semanticscholar.org/d8f2/284ad30e7f28bbe5f750f52c3b8df90db53b.pdf

Tahtalığlu, H. (2018). Türkiye'de elektronik belge yönetim sisteminin kamu personeli tarafindan benimsenmesinde eğitim faktörü. Yasama Dergisi, 37, 124-147. Available at http://www.yasader.org/web/yasama_dergisi/2018/sayi37/sayi37_124-147.pdf 
Tamtürk, E. (2017). Kamu Yönetiminde Elektronik Belge Yönetim Sistemi. Journal of Social Sciences of Muş Alparslan University, 5(3), 851-863. Available at http://dergipark.gov.tr/download/article-file/325152

The ISO/IEC 9126-4 Standard. (2004). Technical report. Available at https://www.sis.se/api/document/preview/904663/

Tiitinen, P., Lyytikäinen, V., Päivärinta, T., and Salminen, A. (2000). User needs for electronic document management in the public administration: A study of two cases. Available at https://aisel.aisnet.org/cgi/viewcontent.cgi?article $=1161 \&$ context=ecis 2000

Wisdom, J., and Creswell, J. W. (2013). Mixed methods: Integrating quantitative and qualitative data collection and analysis while studying patient-centered medical home models. Available at https://pcmh.ahrq.gov/page/mixed-methods-integrating-quantitative-and-qualitative-data collection-and-analysis-while

Yalçınkaya, B. (2016). Elektronik belge yönetim sistemi: EBYS uygulamalarında başarı faktörü ve fayda analizi. AJIT-e: Online Academic Journal of Information Technology, 7(23), 67-96.

Yatin, S.F.M, Ramli, A.A.M., Hashim, H., and Kadir, W.A. (2015). Electronic records management system: Malaysian experience. Australian Journal of Basic and Applied Sciences, 9(3), 82-89. Available at: https://www.researchgate.net/publication/272172912_Electronic_Document_Management System_Malaysian_Experience

Yıldırım, A., and Şimşek, H. (2000). Sosyal bilimlerde nitel araştırma yöntemleri. Ankara: Seçkin Yayınevi.

Yüksek Planlama Kurulu. (2005, 24 Mart). e-Dönüşüm Türkiye Projesi 2005 Y11ı Eylem Planı. Yüksek Planlama Kurulu (Karar numarasi: 2005/5). Available at http://www.resmigazete.gov.tr/Eskiler/2005/04/20050401-12.htm 